\title{
Career success in the University setting: Examining the role of narcissism facets
}

\author{
Cemre Oflu $^{1} \cdot$ Martin M. Baluku ${ }^{1} \cdot$ Kathleen Otto ${ }^{1,2}$ (D) \\ Published online: 18 January 2020 \\ (C) The Author(s) 2020
}

\begin{abstract}
The purpose of this research is to examine the association of narcissism facets with subjective and objective career success, as well as the impact of the professional field. Data from 282 employees of a German university - both scientists and administrative staff - who completed an online survey were analysed. Results showed a significant negative relationship between vulnerable narcissism and career success. The associations of the grandiose narcissism subfacets: grandiose exhibitionism and entitlement/ exploitativeness, as well as vulnerable narcissism with subjective career success were affected by professional field. However, leadership/authority, the remaining subfacet of grandiose narcissism, was not associated with career success.
\end{abstract}

Keywords Dark triad · Narcissism · Career success · Career satisfaction · Professional field

Research on the relationship between personality and career outcome variables, including career success, is an important theme in the field of industrial and organizational (I/O) psychology. As many studies in the past decades have shown, person-organization-fit, the compatibility between the personality of an individual and the culture of an organization (Kristof 1996), is linked to turnover, organizational commitment, task performance, and job satisfaction (Hoffman and Woehr 2006; O'Reilly et al. 1991). Thus, the match between an employee's personality and an employer's organizational culture is an important determinant in whether the work relationship will be beneficial for both parties.

Personality research in organizational psychology has increasingly paid attention to a rather negative set of personality traits labeled as the Dark Triad. Narcissism, one member of the Dark Triad, is possibly more prevalent in specific professional fields such as academics (Hill and Yousey 1998; Jauk and Sordia 2018). Taking not only the work context, but also the professional field into account could contribute to understanding possible trait-situation interactions. The present study investigates the role

this article to Kathleen Otto at: Philipps

Kathleen Otto

kathleen.otto@staff.uni-marburg.de

Philipps University Marburg, Marburg, Germany

2 Faculty of Psychology, Work and Organizational Psychology, Philipps University Marburg, Gutenbergstr. 18, D-35032 Marburg, Germany of narcissism in career success in the university setting. Among the academics (scientists), prestige and peer approval could be determinants of success (Lemaitre 2017), which could be different for the administrators within the same work context. Hence interaction effects of professional field and narcissistic tendency on some aspects of career success are possible.

Subjective career success can be defined as the degree to which individuals feel accomplished and satisfied with their careers, whereas objective career success can be defined as career accomplishments which are extrinsically observable and measurable (Judge et al. 1995). So far, only a few studies have been published that address the relationship between narcissism and career success. For subjective career success, these studies found no significant effects (Bruk-Lee et al. 2009; Hirschi and Jaensch 2015; Jonason et al. 2015; Spurk et al. 2016), weakly positive effects (Michel and Bowling 2013), and weakly negative effects (Kopelman and Mullins 1992; Mathieu 2013; Soyer et al. 2001). For objective success, no significant effects (O'Boyle et al. 2012) or weakly positive effects (Harms et al. 2011; Hirschi and Jaensch 2015; Spurk et al. 2016) were found. The present study analyses the effects of specific facets of narcissism on objective and subjective career success within the university setting.

\section{The Dark Triad}

In 2002, Paulhus and Williams coined the term Dark Triad for the traits narcissism, psychopathy, and Machiavellianism, 
which are not founded on the Big Five (Harms and Spain 2015) and share a callous core (Furnham et al. 2013). This led to an increased interest in these negative traits and to the original paper being cited more than 2500 times to date. To facilitate the joint study of the Dark Triad, short measures such as the Dirty Dozen (Jonason and Webster 2010) and the Short Dark Triad (Jones and Paulhus 2014) were created. These measures capture each trait without distinguishing their features at facet-level, thereby limiting the broad representation of each Dark Triad member (Spain et al. 2014).

Despite the shared callous core, narcissism is more distinct and shows lower intercorrelations with psychopathy and Machiavellianism (Aghababaei and Błachnio 2015; Muris et al. 2017; O'Boyle et al. 2012). In order to be able to have a more in-depth look at a single Dark Triad member by using more distinct and longer measures, this research focuses on the relationship between narcissism facets and career success.

Narcissists are characterized by a grandiose self-perception and exhibitionistic behavior with the goal of obtaining admiration from others, on the one hand, and the hypersensitive vulnerability of their self-esteem to the lack of external validation on the other (Morf and Rhodewalt 2001; Pincus et al. 2009; Wink 1991). Narcissistic individuals can fluctuate between showing these grandiose and vulnerable aspects of the trait (Gore and Widiger 2016).

In line with that, after conducting a principal component analysis of narcissism scales, Wink (1991) labeled the resulting two factors Grandiosity-Exhibitionism and Vulnerability-Sensitivity. In a review of research on the Dark Triad from 2013, Furnham, Richards and Paulhus addressed the necessity of applying this distinction between narcissistic grandiosity and vulnerability when investigating the role of narcissism in different contexts. The listed studies on narcissism and career success do not take this distinction into consideration. Soyer et al. (2001) are an exception from this, finding no significant correlation between career satisfaction and grandiose narcissism, but a weak negative correlation between career satisfaction and vulnerable narcissism measures.

Most studies on the relationship between narcissism and career success have applied the Narcissistic Personality Inventory (NPI, Raskin and Terry 1988), or the Short Dark Triad inventory derived from the NPI (Jones and Paulhus 2014), which mainly capture grandiose aspects of narcissism (Gentile et al. 2013; Morf et al. 2017). The NPI has shaped the conceptualization of narcissism because between 1985 and 2006 , it was used in $77 \%$ of personality and social psychology research on narcissism (Cain et al. 2008). Despite the identification of factor structures for the NPI (e.g. Ackerman et al. 2011), to the authors' knowledge, no study has yet been conducted regarding the relationship between sub-facets of grandiose narcissism and career success. The present study is attempting to shed light on the few and contradicting findings on how narcissism relates to subjective and objective career success by focusing on adaptive and maladaptive facets of the trait.

\section{Grandiose Narcissism}

Grandiose narcissism is linked to higher levels of self-esteem, achievement striving and extraversion, i.e. gregariousness, assertiveness and activity (Miller et al. 2011), and positive affect (Morf et al. 2017), which indicates that there is an adaptive aspect of the construct. In contrast, there is a maladaptive aspect of grandiose narcissism characterized by lower levels of guilt (Morf et al. 2017), agreeableness (Miller et al. 2011), higher levels of neuroticism (Maples et al. 2014), and interpersonal problems (Muris et al. 2017).

In their factor analysis of the NPI, Ackerman et al. (2011) identified three facets of grandiose narcissism: leadership/authority, grandiose exhibitionism and entitlement/ exploitativeness, which will be described in the following in more detail.

Adaptive Grandiose Narcissism. Leadership/authority, i.e. the dimension of self-perceived leadership ability and social potency in grandiose narcissists, is linked to more adaptive variables with the exception of showing a negative association with agreeableness (Gentile et al. 2013; Miller et al. 2011). Ackerman et al. (2011) found a link between the leadership/authority dimension and higher levels of selfesteem and drive, while others reported a connection with higher levels of extraversion (Clarke et al. 2015; Miller et al. 2011), conscientiousness (Clarke et al. 2015; Gentile et al. 2013), and lower levels of neuroticism (Gentile et al. 2013; Miller et al. 2011). For the grandiose exhibitionism facet, which captures narcissistic self-presentation (Ackerman et al. 2011), similar relationships with self-esteem, extraversion and agreeableness were found (Ackerman et al. 2011; Clarke et al. 2015; Gentile et al. 2013), thus indicating a similarly adaptive function of this facet.

Higher levels of self-esteem, drive, extraversion, conscientiousness, and lower levels of neuroticism are linked to higher levels of subjective (Bruk-Lee et al. 2009; Judge and Larsen 2001; Ng et al. 2005; Ng and Feldman 2014) and objective (Judge 2009; Ng et al. 2005) career success. Since leadership/ authority and grandiose exhibitionism are linked to these variables, one can assume that they will have similarly positive association patterns with subjective and objective career success.

H1: Leadership/authority will be associated with (a) more subjective and (b) more objective career success.

H2: Grandiose exhibitionism will be associated with (a) more subjective and (b) more objective career success.

Maladaptive Grandiose Narcissism. In contrast to leadership/authority and grandiose exhibitionism, the entitlement/exploitativeness facet of grandiose narcissism, 
reflecting the entitled beliefs and manipulative tendencies of narcissists, has been identified as being more maladaptive (Emmons 1984). As opposed to the adaptive grandiose narcissism facets, this facet is associated with lower levels of selfesteem (Clarke et al. 2015) and higher levels of neuroticism (Hendin and Cheek 1997). Moreover, entitlement/ exploitativeness positively correlates with anxiety (Emmons 1984) and antisocial tendencies (Gentile et al. 2013).

Lower levels of self-esteem, and higher levels of neuroticism are negatively associated with subjective (Bruk-Lee et al. 2009; Judge and Larsen 2001; Ng et al. 2005; Thoresen et al. 2003) and objective career success (Judge 2009; Ng et al. 2005). Thus, for entitlement/exploitativeness, one can assume a similarly negative association pattern with subjective and objective career success.

H3: Entitlement/exploitativeness will be associated with (a) less subjective and (b) less objective career success.

\section{Vulnerable Narcissism}

When the grandiose self-image of narcissists is threatened due to insufficient external validation, narcissistic vulnerability can lead to experiences of low self-esteem, shame and helplessness (Morf and Rhodewalt 2001; Pincus et al. 2009). Vulnerable narcissism is moderately linked to lower levels of self-esteem (Miller et al. 2011; Pincus et al. 2009), and higher levels of neuroticism (Hendin and Cheek 1997; Miller et al. 2011) and negative affect (Morf et al. 2017). These associations are stronger than those found for maladaptive grandiose narcissism, which emphasizes the idea that narcissistic vulnerability is the more maladaptive spectrum of narcissism (Morf et al. 2017; Wink 1991). Lower levels of self-esteem, and higher levels of neuroticism and negative affect are negatively associated with subjective (Judge and Larsen 2001; Thoresen et al. 2003) and objective career success (Judge 2009; Ng et al. 2005). Therefore, for vulnerable narcissism, one can assume similar negative association patterns with subjective and objective career success.

H4: Vulnerable narcissism will be associated with (a) less subjective and (b) less objective career success.

\section{Subjective Career Success and the Role of Professional Field}

Subjective career success is often operationalized as an individual's career satisfaction relative to criteria for success. The frequently used Career Satisfaction Scale (Greenhaus et al. 1990) is an example of such an operationalization. Due to the rigid organizational structure of German universities in regard to salaries and promotions, the comparison between professional fields was limited to subjective career success.

Person-job-fit describes the extent to which an individual's values, preferences, and needs match a job's requirements, and it positively affects career outcomes such as job satisfaction and performance (Brkich et al. 2002; Edwards 1991). Hence, narcissistic traits in individuals might have differing effects on career success depending on the individual's job or professional field.

Individuals with higher levels of narcissism show a need for autonomy (Mullins and Kopelman 1988), choose professions that facilitate social approval, and they perceive their workplace as more prestigious and less restrictive (Jonason et al. 2015). Thus, jobs in academics, which are often perceived as prestigious and admirable (Hill and Yousey 1998) might be an attractive professional field for narcissists. A high need for admiration and skill demonstration might be a determinant of selecting a career in the scientific field (Jauk and Sordia 2018). Striving for skill demonstration is positively linked to narcissism in junior scientists (Janke et al. 2019).

Published studies on narcissism in academia are still scarce, however, it has recently been argued that the scientific field is an appropriate environment to study the narcissistic personality trait (Lemaitre 2017). The chance of becoming a professor, who can work autonomously and holds a prestigious and powerful position (Enders 2001), can further increase the attractiveness of this professional field. As sources of possible validation, the work of scientists involves constant evaluations of their work by colleagues through peer reviews and citations, as well as performance comparisons through the number of their scientific publications or research productivity scores. Narcissists' need for recognition might drive them to perform better in science (Lemaitre 2017). Scientists involved in the education and mentoring of students might see this as a further source of external validation.

For the administrators within the university setting, to the best of the authors' knowledge, there is no research addressing non-pathological narcissism. The only publication found on this specific group of professionals is Misch's (2002) description of an administrative character type he observed in academic institutions and labeled "as-if faculty/student advocate". This character type shows parallels to the narcissism concept, as it is characterized by a constantly high need for validation and callousness (Misch 2002).

University administrators are a contrast sample to the sample of scientists. In contrast to jobs in academics, jobs in the university administration do not offer the same opportunities for public recognition, as publishing is not a key element in administrative professions. Therefore, it is assumed that the link between narcissism facets and subjective career success will be weaker in the administrative field than in the scientific field.

The positive association of subjective career success with (H5) leadership/authority; and (H6) grandiose exhibitionism will be larger for academic staff than for administrative staff.

The negative association of subjective career success with (H7) entitlement/exploitativeness; and (H8) vulnerable 
narcissism will be larger for academic staff than for administrative staff.

\section{Method}

\section{Participants}

Academic and administrative staff was recruited to participate in the study $(N=282)$. All academic and administrative staff of a German university received email invitations to complete the online survey. In addition, academic staff from other universities was targeted through email invitations. Participants could choose between a German or an English version of the survey. Of the participants, $69.1 \%$ were female, while $30.9 \%$ identified as male, with their ages ranging from 19 to 76 years $(M=38.81, S D=11.00)$. Moreover, 54.3\% $(N=153)$ of the participants worked in the academic field, whereas $45.7 \%$ $(N=129)$ worked in the university administration. On average, participants from the academic sample had been working in their current professions for 6.58 years $(S D=7.62)$, compared to 12.90 years $(S D=11.05)$ for administrators. The mean for average weekly working hours was 41.13 ( $S D=$ $12.75)$ in the academic sample, and $36.38(S D=8.46)$ in the administrative sample.

\section{Instruments}

Narcissism measures. Grandiose narcissism was measured using a modified version of the NPI-13 (Gentile et al. 2013). Three items from the Grandiose Exhibitionism scale ("I like to look at myself in the mirror.", "I like to show off my body.", and "I like to look at my body.") were eliminated because they measure physical aspects of exhibitionism (Raskin and Terry 1988), which are less relevant for the measurement of narcissism in the academic and administrative context. These items were replaced with two different items which load on the grandiose exhibitionism factor ("I like to be the center of attention.", "I like to be complimented.") retrieved from the NPI-40 (Ackerman et al. 2011). A translation of the NPI items (Schütz et al. 2004) was used for the German version of the survey.

Brailovskaia et al. (2019) validated this German version and its subscales, and obtained satisfactory factor analysis results for its three-factor structure. The modified version of the NPI-13 had a Cronbach's $\alpha$ of .75. The leadership/ authority and grandiose exhibitionism subscales measured adaptive grandiose narcissism, while the entitlement/ exploitativeness subscale measured maladaptive grandiose narcissism. Cronbach's alpha levels for the subscales of the modified NPI-13 (see Table 1) were slightly below the commonly recommended alpha level of .70 to .90 (Nunnally 1978), which might be due to the small number of items included in the subscales (Streiner 2003). As an alternative measure for internal consistency to avoid issues related to scale length, Clark and Watson (1995) recommend to calculate inter-item correlations of scales, which should be between .15 and .50. The mean inter-item correlations of .36 for leadership/authority, .30 for grandiose exhibitionism, and .28 for entitlement/exploitativeness all fall into this range.

For the measurement of vulnerable narcissism, the original English version of the Hypersensitive Narcissism scale (HSNS; Hendin and Cheek 1997), and a German translation (Köberl 2015) were used.

\section{Career Success Measures}

To measure subjective career success, the Career Satisfaction Scale (CSS, Greenhaus et al. 1990) and its German translation (Abele and Spurk 2009) were used. To measure objective career success, participants working in the academic field were asked to report the number of their publications in peer reviewed journals.

Professional field and control variables. The professional field of participants was assessed with a single-choice item containing the options "academic" and "administrative". To control for possible confounding effects, participants were asked to indicate their age, gender, weekly working hours, and how long they had been working in their profession.

\section{Procedure}

First, participants chose between starting the German or English language version of the online survey. In the selected language, they were informed that the purpose of the online survey was to assess career success in the university setting and its relationship with personal variables. Next, they were informed that responses were collected anonymously, and that by consenting to participate, they would give the researchers permission to use their responses in research on an aggregated level. They were also informed that they may withdraw from participation at any time. Participants were asked to click the "Next" button if they consented to participate. Following this, they were asked to indicate their age, gender, weekly working hours, professional field, and how long they had been working in their profession. Then, they completed the career success measures followed by the narcissism measures in randomized order.

\section{Analytic Strategy}

To test hypotheses H1a, H2a, H3a, H4a, and $\mathrm{H} 5$ to H8, a hierarchical regression analysis was performed predicting subjective career success. In the first step, the control variables were entered into the regression model, whereas the second step included the narcissism facets and professional field, and 
Table 1 Descriptive Statistics, Reliabilities, and Intercorrelations of the Measures

\begin{tabular}{|c|c|c|c|c|c|c|c|c|c|c|c|}
\hline Measure & 1 & 2 & 3 & 4 & 5 & 6 & 7 & 8 & 9 & 10 & 11 \\
\hline$N$ Items & 1 & 1 & 1 & 1 & 4 & 4 & 4 & 10 & 1 & 5 & 1 \\
\hline$M$ & 38.81 & 0.31 & 38.96 & 9.47 & 3.14 & 3.31 & 3.12 & 2.98 & 0.54 & 3.97 & 10.91 \\
\hline$S D$ & 11.00 & 0.46 & 11.23 & 9.85 & 0.82 & 0.77 & 0.82 & 0.69 & - & 1.02 & 32.83 \\
\hline 1. Age & - & & & & & & & & & & \\
\hline 2. Gender & .00 & - & & & & & & & & & \\
\hline 3. Weekly Working Hours & -.03 & $.31 * *$ & - & & & & & & & & \\
\hline 4. Years spent in Profession & $.80 * *$ & -.01 & .04 & - & & & & & & & \\
\hline 5. Leadership/Authority & -.04 & $.23 * *$ & $.19 * *$ & .01 & $(.69)$ & & & & & & \\
\hline 6. Grandiose Exhibitionism & -.03 & .06 & -.04 & -.06 & $.25 * *$ & (.63) & & & & & \\
\hline 7. Entitlement/Exploitativeness & $-.17 * *$ & $.11 *$ & .10 & $-.14 *$ & $.36^{* *}$ & $.39 * *$ & $(.61)$ & & & & \\
\hline 8. Vulnerable Narcissism & $-.29 *$ & .03 & -.01 & $-.28 * *$ & -.07 & $.17 * *$ & $.36^{* *}$ & $(.76)$ & & & \\
\hline 9. Professional Field & $-.40 * *$ & $.23 * *$ & $.21 * *$ & $-.32 * *$ & $.14 *$ & -.05 & .02 & .04 & - & & \\
\hline 10. Subjective Career Success & .05 & $.15^{* *}$ & $.19 * *$ & .04 & $.12 *$ & .05 & .00 & $-.23 * *$ & .07 & $(.87)$ & \\
\hline 11. Objective Career Success & $.51 * *$ & $.27 * *$ & $.30 * *$ & $.58 * *$ & .10 & -.09 & .04 & $-.24 * *$ & - & $.21 * *$ & - \\
\hline
\end{tabular}

Cronbach's Alpha in brackets; $N$ Items = number of Items, $M=$ mean, $S D=$ standard deviation; gender: $0=$ female, $1=$ male; professional field: $0=$ administrative, 1 = academic

$* p<.05 ; * *<<.01$

the third step included the moderation effects. To further examine the moderation effect of professional field on the relationship between narcissism facets and subjective career success, simple slope analyses were conducted. To test hypotheses $\mathrm{H} 1 \mathrm{~b}, \mathrm{H} 2 \mathrm{~b}, \mathrm{H} 3 \mathrm{~b}$ and $\mathrm{H} 4 \mathrm{~b}$, a second hierarchical regression analysis was conducted predicting the number of publications. As three participants in the academic sample indicated they did not know their number of publications, the final sample size was 150 . In the first step of the regression analysis, the control variables were entered, while the second step included narcissism facets.

\section{Results}

\section{Narcissism Facets and Career Success}

In Table 1, the descriptive statistics, reliabilities, and intercorrelations of the different measures are presented. In line with predictions, from the grandiose narcissism facets, leadership/ authority significantly and positively correlated with subjective career success. Vulnerable narcissism significantly and negatively correlated with subjective career success in the overall sample, as well as the number of publications in the academic sample.

The results of the hierarchical multiple regression analyses for subjective and objective career success are presented in Tables 2 and 3, respectively. As hypothesized, vulnerable narcissism was a significant predictor of less subjective career success after controlling for age, gender, weekly working hours, and how long participants had been working in their professions. However, contrary to predictions, leadership/authority, grandiose exhibitionism, and entitlement/ expoitativeness did not predict variance in subjective career success in the overall sample.

For objective career success, higher levels of vulnerable narcissism significantly predicted fewer scientific publications in the academic sample, supporting hypothesis H4b. Leadership/authority, grandiose exhibitionism, and entitlement/exploitativeness did not significantly predict variance in objective career success. Thus, hypotheses H1b, H2b, and $\mathrm{H} 3 \mathrm{~b}$ were not supported by the results. Separate regression analyses for the academic and administrative subsamples yielded similar results.

\section{Narcissism Facets, Professional Field, and Subjective Career Success}

In the third step of the hierarchical regression analysis predicting subjective career success, moderation effects of narcissism facets and professional field were examined (Table 2). In this step, the regression weights for the narcissism facets describe the relationship between the facets and subjective career success when the moderator has the value zero (Friedrich 1982), meaning when participants work in the administrative field. When the moderation effects for narcissism facets and professional field were taken into account in the third step, grandiose exhibitionism significantly predicted more subjective career success in the administrative sample, partially supporting hypothesis H2a, but contradicting H6. Contrary to predictions, the significant negative association between vulnerable narcissism and subjective career success 
Table 2 Hierarchical Multiple Regressions to Examine the Direct Effects of Narcissism Facets on Subjective Career Success, Considering Moderating Effects of Professional Field

\begin{tabular}{|c|c|c|c|c|c|c|}
\hline & \multicolumn{2}{|l|}{ Step 1} & \multicolumn{2}{|l|}{ Step 2} & \multicolumn{2}{|c|}{ Step 3} \\
\hline & $B$ & $S E B$ & $B$ & $S E B$ & $B$ & $S E B$ \\
\hline \multicolumn{7}{|l|}{ Control Variables } \\
\hline Age & .09 & .10 & .06 & .10 & .04 & .10 \\
\hline Gender & .21 & .14 & .19 & .14 & .18 & .14 \\
\hline Weekly Working Hours & $.17 * *$ & .06 & $.16^{* *}$ & .06 & $.17 * *$ & .06 \\
\hline Years spent in Profession & -.03 & .10 & -.07 & .10 & -.07 & .10 \\
\hline \multicolumn{7}{|l|}{ Main Effects } \\
\hline Leadership/Authority & & & .02 & .07 & .07 & .10 \\
\hline Grandiose Exhibitionism & & & .08 & .06 & $.17^{*}$ & .10 \\
\hline Entitlement/Exploitativeness & & & .04 & .07 & -.16 & .11 \\
\hline Vulnerable Narcissism & & & $-.27 * * *$ & .07 & -.12 & .10 \\
\hline Professional Field & & & .07 & .13 & .92 & .79 \\
\hline \multicolumn{7}{|l|}{ Interaction Effects } \\
\hline Leadership/Authority x Professional Field & & & & & -.15 & .28 \\
\hline Grandiose Exhibitionism x Professional Field & & & & & -.37 & .29 \\
\hline Entitlement/Exploitativeness x Professional Field & & & & & $.69^{* *}$ & .30 \\
\hline Vulnerable Narcissism x Professional Field & & & & & $-.63^{*}$ & .30 \\
\hline$\Delta R^{2}(F)$ & \multicolumn{2}{|c|}{$.05 * *(3.52)$} & \multicolumn{2}{|c|}{$.06^{* *}(3.86)$} & \multicolumn{2}{|c|}{$.03(2.04)$} \\
\hline
\end{tabular}

$B=$ unstandardized regression coefficient, $S E B=$ standard error of the regression coefficient, $\Delta R^{2}=$ additional explained variance; gender: $0=$ female, $1=$ male; professional field: $0=$ administrative, $1=$ academic

$* p<.05 ; * * p<.01 ; * * * p<.001$

found for the overall sample in the second step of the regression analysis diminished. As presented in Fig. 1, the effect of entitlement/exploitativeness on subjective career success was larger for participants from the academic field than for participants from the administrative field. Although the difference

Table 3 Hierarchical Multiple Regressions to Examine the Direct Effects of Narcissism Facets on Objective Career Success

\begin{tabular}{|c|c|c|c|c|}
\hline & \multicolumn{2}{|l|}{ Step 1} & \multicolumn{2}{|l|}{ Step 2} \\
\hline & $B$ & $S E B$ & $B$ & $S E B$ \\
\hline \multicolumn{5}{|l|}{ Control Variables } \\
\hline Age & -.95 & 5.59 & -2.31 & 5.67 \\
\hline Gender & 5.63 & 4.74 & 6.90 & 4.76 \\
\hline Weekly Working Hours & $5.45^{* *}$ & 1.97 & $5.51 * *$ & 2.02 \\
\hline Years spent in Profession & $24.19 * * *$ & 6.02 & $23.97 * * *$ & 6.11 \\
\hline \multicolumn{5}{|l|}{ Main Effects } \\
\hline Leadership/Authority & & & -1.76 & 2.53 \\
\hline Grandiose Exhibitionism & & & -3.25 & 2.40 \\
\hline Entitlement/Exploitativeness & & & 3.28 & 2.54 \\
\hline Vulnerable Narcissism & & & $-4.21 *$ & 2.44 \\
\hline$\Delta R^{2}(F)$ & \multicolumn{2}{|c|}{$.39 * * *(22.90)$} & \multicolumn{2}{|l|}{$.02(1.46)$} \\
\hline
\end{tabular}

$B=$ unstandardized regression coefficient, $S E B=$ standard error of the regression coefficient, $\Delta R^{2}=$ additional explained variance; gender: $0=$ female, $1=$ male

$* p<.05 ; * * p<.01 ; * * * p<.001$ in effect sizes between the academic and administrative field is in line with predictions, the positive direction of the effect is contrary to what was hypothesized. As presented in Fig. 2, and in accordance with predictions, the negative association of vulnerable narcissism and subjective career success was larger for academic staff than for administrative staff. Contrary to predictions, the effects of leadership/authority and grandiose exhibitionism on subjective career success were not moderated by professional field.

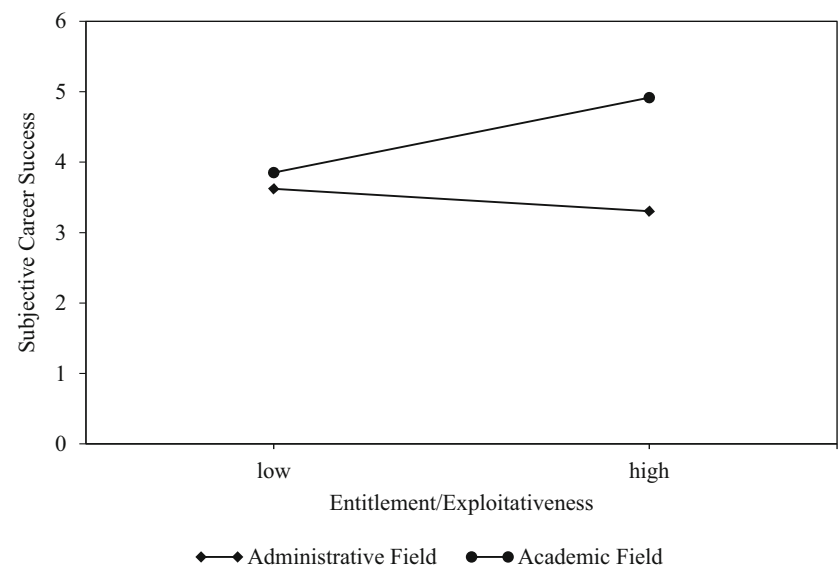

Fig. 1 Relationship of entitlement/exploitativeness with subjective career success in the administrative and academic professional fields Interaction Effect of Vulnerable Narcissism and Professional Field on Subjective Career Success. 


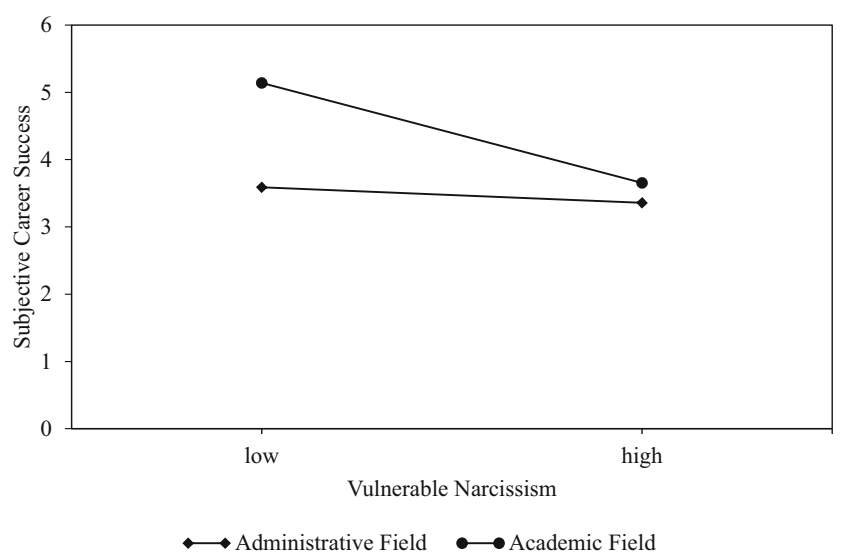

Fig. 2 Relationship of vulnerable narcissism with subjective career success in the administrative and academic professional fields

\section{Discussion}

The aim of this study was to investigate how facets of narcissism relate to subjective and objective career success, and whether the professional field within the university setting affects the relations between facets of narcissism and subjective career success. This research showed that vulnerable narcissism predicted lower levels of subjective and objective career success. Moreover, the adaptive grandiose narcissism facet grandiose exhibitionism significantly predicted higher levels of subjective career success in the administrative field, but this facet was not related to objective career success. The adaptive grandiose narcissism facet leadership/authority did not predict subjective or objective career success.

Entitlement/exploitativeness was not associated with subjective or objective career success in the overall sample. However, when the role of professional field was taken into consideration, the association between entitlement/ exploitativeness and subjective career success was affected. The effects of entitlement/exploitativeness and vulnerable narcissism were larger for academic staff than for administrative staff. Furthermore, there were no significant moderation effects of professional field in the cases of leadership/authority and grandiose exhibitionism.

In regard to subjective career success, both, subfacets of grandiose narcissism, and vulnerable narcissism seem to be meaningful constructs. A grandiose and exhibitionistic selfpresentation relates to how satisfied administrative staff is with their success at work. This finding confirms the idea that some thinking patterns and convictions of individuals showing narcissistic traits can be adaptive because they relate to a more positive perception of professional accomplishments and career success (Jonason et al. 2015; O’Boyle et al. 2012).

In contrast, the negative association between vulnerable narcissism and subjective career success found for academic staff shows that thinking patterns and convictions which are a part of narcissistic vulnerability can be related to individuals being less satisfied with their careers (Kopelman and Mullins 1992; Soyer et al. 2001). Following the definition of narcissism (Morf and Rhodewalt 2001; Wink 1991), external validation and admiration are important to scientists who show high levels of vulnerable narcissism, and they are sensitive to a lack of external validation. Hence, an explanation for vulnerably narcissistic scientists being less satisfied with their careers could be that they perceive the amount of validation they receive to be insufficient.

In regard to objective career success, narcissistic vulnerability is the only facet of narcissism which is a significant predictor. Whether individuals working in the academic field have a hypersensitive self-esteem and are self-conscious plays a role in how productive they are at their jobs when it comes to the number of papers they publish. The more vulnerable individuals working in the academic field are to a perceived lack of appraisal, the fewer papers they publish in scientific journals. One possible explanation for this could be that narcissistic vulnerability discourages scientists from entering the rigorous peer review process for publishing in scientific journals.

Furthermore, the professional field within the university context seems to play a role in the link between facets of narcissism and subjective career success. More precisely, narcissistic entitlement/exploitativeness relates to an increase of subjective career success in the academic sample, but it is not associated with subjective career success in the administrative sample. Although the positive direction of this effect is deviant from what was predicted, this result shows that entitlement/exploitativeness has different consequences for career satisfaction depending on the professional field. One possible explanation for this could be that individuals showing this facet of narcissism in the academic field could perceive their self-entitling demands and need for respect to be met more than similarly narcissistic individuals in the administrative field. Thus, whether narcissistic entitlement relates positively or negatively to subjective career success might vary depending on the specific professional field and its potential for meeting an individual's demands of self-entitlement and respect.

Besides narcissistic entitlement and exploitativeness, vulnerable narcissism also relates differently to subjective career success depending on the professional field of university staff. Vulnerable narcissism is negatively associated with subjective career success in the academic field, while it is not related to subjective career success in the administrative field. This might be due to scientists being more often and more explicitly exposed to the evaluation of their work by their colleagues than it is the case for administrators. Consequently, it could be that academic staff showing tendencies of vulnerable narcissism is exposed to more situations of evaluation in which they experience the amount of validation they receive from others to be inadequate. 
In the university setting, not all facets of narcissism that were examined seem to play a role when it comes to career success. The perception of oneself as a good leader does not appear to relate to how satisfied university staff is with their success at work, or how many papers the academic staff publishes. This could be due to the fact that most participants in this study were early career academics. Or, the perceived leadership ability of narcissistic individuals could be deviant from their actual leadership ability.

Although this research gives new and distinct insights into the relationship between facets of narcissism, professional field, and career success, limitations have to be mentioned. It is important to highlight that the cross-sectional design of the study does not permit conclusions about causal relationships between the variables. For the assessment of the variables, only self-report measures were included. Moreover, participation was voluntary, and, although gender was controlled for, the majority of the sample was female. Overall, more research needs to be conducted on the association between narcissism, professional field, and career success to draw clearer conclusions.

\section{Directions for Future Research and Practical Implications}

From the limitation of this study, suggestions for future research can be derived. First, a longitudinal study design could help to detect causal relationships between narcissism and career success. Alternatively, a quasiexperimental design could help to detect the influence of narcissism and its facets on general performance. Regarding the measurements of narcissism facets and of career success, other-report measures could be a valuable addition. By comparing self-reports to other-reports, possible discrepancies could be detected.

On a more general note, Jonason et al. (2014) found that narcissism was associated with enterprising, social, and artistic vocational interests. Similarly, in a recently published study, Kowalski et al. (2017) found significant positive correlations between NPI scores and vocational interest in arts, business, and to a lesser extent, biology as well as the social field. Hill and Yousey (1998) found higher NPI scores for politicians than for professors. Therefore, research addressing narcissism and the role of professional field should include these fields, as well. Furthermore, depending on the professional field, shortand long-term impression management could potentially mediate the effects of narcissism facets on career success (Harms and Spain 2015; Paulhus 1998).
Apart from the implications for future research, practical implications can be derived from this study, as well. To begin with, it is important to note that it is not reasonable to derive general measures which target broad groups or all employees of organizations. Instead, the adequacy of applying measures related to narcissism should be thoroughly considered in each individual case and depend on the context and whether an employee actually shows narcissistic tendencies.

For instance, I/O psychologists or other specialists who are familiar with the concept of narcissism could address issues related to vulnerable narcissism and low subjective career success. In coaching situations or similar one-to-one interactions with individuals showing signs of narcissistic vulnerability, by incorporating cognitive restructuring methods to change maladaptive thoughts, subjective career success could be increased. As an example, in a coaching session, it could be emphasized that perceived lack of validation from others is not a reason for dissatisfaction with one's career. Coaches could help employees with narcissistic tendencies to recognize that relying more on internal validation rather than an extensive need for external validation could be beneficial for their career satisfaction.

Whether findings on narcissism are applicable in personnel selection situations has been debated before due to social desirability issues and the resulting difficulty in detecting narcissism in interview situations, as well as ethical concerns (Smith et al. 2016; Spain et al. 2014). Given the fact that there is little research on narcissism facets and career outcomes, more research in this field is necessary to derive further practical implications.

Overall, this research extends previous findings on narcissism and subjective and objective career success by investigating the trait at facet-level and considering the role of professional field. It is the first study, to the best of the authors' knowledge, which found significant results for subjective and objective career success being associated with vulnerable narcissism, and subfacets of grandiose narcissism (i.e. grandiose exhibitionism, entitlement/ exploitativeness) being associated with subjective career success. These results specifically demonstrate that vulnerable narcissism as well as entitlement and exploitativeness are important for subjective career success among scientific staff. However, more research needs to be conducted to clarify the relationship between narcissism facets, professional field, and career success. Especially, further examining the role of objective career success beyond the number of publications in an academic sample would add to the findings from this research and explain if narcissism is related to objective career success in other professional fields, as well. 
Author Contributions CO developed the study concept and was as the principal investigator responsible for data collection and drafting the manuscript. $\mathrm{MB}$ and $\mathrm{KO}$ reviewed the study concept and participated in the data analysis and development of the manuscript.

Funding Information Open Access funding provided by Projekt DEAL.

\section{Compliance with Ethical Standards}

Conflict of Interests On behalf of all authors, the corresponding author states that there is no conflict of interest.

Ethics Statement The authors declare that all the procedures performed in conducting the study were in accordance with the ethical guidelines of the German Psychological Society (DGPs): https://www.dfg.de/ foerderung/faq/geistes_sozialwissenschaften/index.html. Accordingly, no ethical approval was required because the study did not pose any threats or risks to the respondents. The study did not involve procedures that are associated high physical or emotional stress. Respondents were informed about the objectives of the study and also informed that the data are collected anonymously and strictly for the purpose of this study. No identifying information was collected. Participation in the study was voluntarily. Respondents also indicated their consent to participate in the study. Nevertheless, a written informed consent was not obtained explicitly from participants due to the online-assessment technique employed, and as this approach would have endangered participant's anonymity. Incomplete responses were not included in the analyses and were also deleted from the dataset.

Open Access This article is licensed under a Creative Commons Attribution 4.0 International License, which permits use, sharing, adaptation, distribution and reproduction in any medium or format, as long as you give appropriate credit to the original author(s) and the source, provide a link to the Creative Commons licence, and indicate if changes were made. The images or other third party material in this article are included in the article's Creative Commons licence, unless indicated otherwise in a credit line to the material. If material is not included in the article's Creative Commons licence and your intended use is not permitted by statutory regulation or exceeds the permitted use, you will need to obtain permission directly from the copyright holder. To view a copy of this licence, visit http://creativecommons.org/licenses/by/4.0/.

\section{References}

Abele, A. E., \& Spurk, D. (2009). How do objective and subjective career success interrelate over time? Journal of Occupational and Organizational Psychology, 82(4), 803-824. https://doi.org/10. 1348/096317909X470924.

Ackerman, R. A., Witt, E. A., Donnellan, M. B., Trzesniewski, K. H., Robins, R. W., \& Kashy, D. A. (2011). What does the narcissistic personality inventory really measure? Assessment, 18(1), 67-87. https://doi.org/10.1177/1073191110382845.

Aghababaei, N., \& Błachnio, A. (2015). Well-being and the dark triad. Personality and Individual Differences, 86, 365-368. https://doi. org/10.1016/j.paid.2015.06.043.

Brailovskaia, J., Bierhoff, H.-W., \& Margraf, J. (2019). How to identify narcissism with 13 items? Validation of the German narcissistic personality inventory-13 (G-NPI-13). Assessment, 26(4), 630 644. https://doi.org/10.1177/1073191117740625.
Brkich, M., Jeffs, D., \& Carless, S. A. (2002). A global self-report measure of person-job fit. European Journal of Psychological Assessment, 18(1), 43-51. https://doi.org/10.1027//1015-5759.18. 1.43.

Bruk-Lee, V., Khoury, H. A., Nixon, A. E., Goh, A., \& Spector, P. E. (2009). Replicating and extending past personality/job satisfaction meta-analyses. Human Performance, 22(2), 156-189. https://doi. org/10.1080/08959280902743709.

Cain, N. M., Pincus, A. L., \& Ansell, E. B. (2008). Narcissism at the crossroads: Phenotypic description of pathological narcissism across clinical theory, social/personality psychology, and psychiatric diagnosis. Clinical Psychology Review, 28(4), 638-656. https://doi.org/ 10.1016/j.cpr.2007.09.006.

Clark, L. A., \& Watson, D. (1995). Constructing validity: Basic issues in objective scale development. Psychological Assessment, 7(3), 309 319. https://doi.org/10.1037/1040-3590.7.3.309.

Clarke, I. E., Karlov, L., \& Neale, N. J. (2015). The many faces of narcissism: Narcissism factors and their predictive utility. Personality and Individual Differences, 81, 90-95. https://doi.org/10.1016/j. paid.2014.11.021.

Edwards, J. R. (1991). Person-job fit: A conceptual integration, literature review, and methodological critique. International Review of Industrial and Organizational Psychology, 6, 283-357.

Emmons, R. A. (1984). Factor analysis and construct validity of the narcissistic personality inventory. Journal of Personality Assessment, 48(3), 291-300. https://doi.org/10.1207/ s15327752jpa4803 11 .

Enders, J. (2001). A chair system in transition: Appointments, promotions, and gate-keeping in German higher education. Higher Education, 41, 3-25. https://doi.org/10.1023/A:1026790026117.

Friedrich, R. J. (1982). In defense of multiplicative terms in multiple regression equations. American Journal of Political Science, 26(4), 797. https://doi.org/10.2307/2110973.

Furnham, A., Richards, S. C., \& Paulhus, D. L. (2013). The dark triad of personality: A 10 year review. Social and Personality Psychology Compass, 7(3), 199-216. https://doi.org/10.1111/spc3.12018.

Gentile, B., Miller, J. D., Hoffman, B. J., Reidy, D. E., Zeichner, A., \& Campbell, W. (2013). A test of two brief measures of grandiose narcissism: The narcissistic personality Inventory-13 and the narcissistic personality Inventory-16. Psychological Assessment, 25(4), 1120-1136. https://doi.org/10.1037/a0033192.

Gore, W. L., \& Widiger, T. A. (2016). Fluctuation between grandiose and vulnerable narcissism. Personality Disorders: Theory, Research, and Treatment, 7(4), 363-371. https://doi.org/10.1037/per0000181.

Greenhaus, J. H., Parasuraman, S., \& Wormley, W. M. (1990). Effects of race on organizational experience, job performance evaluations, and career outcomes. Academy of Management Journal, 33(1), 64-86. https://doi.org/10.2307/256352.

Harms, P., \& Spain, S. M. (2015). Beyond the bright side: Dark personality at work. Applied Psychology, 64(1), 15-24. https://doi.org/10. 1111/apps.12042.

Harms, P. D., Spain, S. M., \& Hannah, S. T. (2011). Leader development and the dark side of personality. The Leadership Quarterly, 22(3), 495-509. https://doi.org/10.1016/j.leaqua.2011.04.007.

Hendin, H. M., \& Cheek, J. M. (1997). Assessing hypersensitive narcissism: A reexamination of Murray's Narcism scale. Journal of Research in Personality, 31(4), 588-599. https://oi.org/10.1006/ jrpe.1997.2204.

Hill, R. W., \& Yousey, G. P. (1998). Adaptive and maladaptive narcissism among university faculty, clergy, politicians, and librarians. Current Psychology, 17(2-3), 163-169. https://doi.org/10.1007/s12144998-1003-x.

Hirschi, A., \& Jaensch, V. K. (2015). Narcissism and career success: Occupational self-efficacy and career engagement as mediators. 
Personality and Individual Differences, 77, 205-208. https://doi. org/10.1016/j.paid.2015.01.002.

Hoffman, B. J., \& Woehr, D. J. (2006). A quantitative review of the relationship between person-organization fit and behavioral outcomes. Journal of Vocational Behavior, 68(3), 389-399. https:// doi.org/10.1016/j.jvb.2005.08.003.

Janke, S., Daumiller, M., \& Rudert, S. C. (2019). Dark pathways to achievement in science: Researchers' achievement goals predict engagement in questionable research practices. Social Psychological and Personality Science, 10(6), 783-791. https://doi.org/10.1177/ 1948550618790227.

Jauk, E., \& Sordia, N. (2018). On risks and side effects: Does creative accomplishment make us narcissistic? Creativity. Theories Research - Applications, 5(2), 182-187. https://doi.org/10.1515/ ctra-2018-0017.

Jonason, P. K., \& Webster, G. D. (2010). The dirty dozen: A concise measure of the dark triad. Psychological Assessment, 22(2), 420 432. https://doi.org/10.1037/a0019265.

Jonason, P. K., Wee, S., Li, N. P., \& Jackson, C. (2014). Occupational niches and the dark triad traits. Personality and Individual Differences, 69, 119-123. https://doi.org/10.1016/j.paid.2014.05. 024.

Jonason, P. K., Wee, S., \& Li, N. P. (2015). Competition, autonomy, and prestige: Mechanisms through which the dark triad predict job satisfaction. Personality and Individual Differences, 72, 112-116. https://doi.org/10.1016/j.paid.2014.08.026.

Jones, D. N., \& Paulhus, D. L. (2014). Introducing the short dark triad (SD3): A brief measure of dark personality traits. Assessment, 21(1), 28-41. https://doi.org/10.1177/1073191113514105.

Judge, T. A. (2009). Core self-evaluations and work success. Current Directions in Psychological Science, 18(1), 58-62. https://doi.org/ 10.1111/j.1467-8721.2009.01606.x.

Judge, T. A., \& Larsen, R. J. (2001). Dispositional affect and job satisfaction: A review and theoretical extension. Organizational Behavior and Human Decision Processes, 86(1), 67-98. https:// doi.org/10.1006/obhd.2001.2973.

Judge, T. A., Cable, D. M., Boudreau, J. W., \& Bretz, R. D. (1995). An empirical investigation of the predictors of executive career success. Personnel Psychology, 48(3), 485-519. https://doi.org/10.1111/j. 1744-6570.1995.tb01767.x.

Köberl, S. (2015). Psychopathische und narzisstische Tendenzen [psychopathic and narcissistic tendencies] (doctoral dissertation). Universität Wien. Retrieved from http://othes.univie.ac.at/39157/

Kopelman, R., \& Mullins, L. (1992). Is narcissism inversely related to satisfaction? An examination of data from two U.S. samples. The Journal of Psychology, 126(2), 121-130. https://doi.org/10.1080/ 00223980.1992 .10543346

Kowalski, C. M., Vernon, P. A., \& Schermer, J. A. (2017). Vocational interests and dark personality: Are there dark career choices? Personality and Individual Differences, 104, 43-47. https://doi. org/10.1016/j.paid.2016.07.029.

Kristof, A. L. (1996). Person-organization fit: An integrative review of its conceptualizations, measurement, and implications. Personnel Psychology, 49(1), 1-49. https://doi.org/10.1111/j.1744-6570.1996. tb01790.x.

Lemaitre, B. (2017). Science, narcissism and the quest for visibility. The FEBS Journal, 284, 875-882. https://doi.org/10.1111/febs.14032.

Maples, J. L., Lamkin, J., \& Miller, J. D. (2014). A test of two brief measures of the dark triad: The dirty dozen and short dark triad. Psychological Assessment, 26(1), 326-331. https://doi.org/10. 1037/a0035084.

Mathieu, C. (2013). Personality and job satisfaction: The role of narcissism. Personality and Individual Differences, 55(6), 650-654. https://doi.org/10.1016/j.paid.2013.05.012.

Michel, J. S., \& Bowling, N. A. (2013). Does dispositional aggression feed the narcissistic response? The role of narcissism and aggression in the prediction of job attitudes and counterproductive work behaviors. Journal of Business and Psychology, 28(1), 93-105. https://doi. org/10.1007/s10869-012-9265-6.

Miller, J. D., Hoffman, B. J., Gaughan, E. T., Gentile, B., Maples, J., \& Keith, C. W. (2011). Grandiose and vulnerable narcissism: A nomological network analysis. Journal of Personality, 79(5), 1013-1042. https://doi.org/10.1111/j.1467-6494.2010.00711.x.

Misch, D. A. (2002). The "as if" faculty/student advocate. Educational Management \& Administration, 30(4), 461-467. https://doi.org/10. 1177/0263211X020304007.

Morf, C. C., \& Rhodewalt, F. (2001). Unraveling the paradoxes of narcissism: A dynamic self-regulatory processing model. Psychological Inquiry, 12(4), 177-196. https://doi.org/10.1207/ S15327965PLI1204 1.

Morf, C. C., Schürch, E., Küfner, A., Siegrist, P., Vater, A., Back, M., et al. (2017). Expanding the nomological net of the pathological narcissism inventory: German validation and extension in a clinical inpatient sample. Assessment, 24(4), 419-443. https://doi.org/10. 1177/1073191115627010.

Mullins, L., \& Kopelman, R. (1988). Toward an assessment of the construct validity of four measures of narcissism. Journal of Personality Assessment, 52(4), 610-625. https://doi.org/10.1207/ s15327752jpa5204_2.

Muris, P., Merckelbach, H., Otgaar, H., \& Meijer, E. (2017). The malevolent side of human nature: A meta-analysis and critical review of the literature on the dark triad (narcissism, Machiavellianism, and psychopathy). Perspectives on Psychological Science, 12(2), 183204. https://doi.org/10.1177/1745691616666070.

Ng, T. W. H., \& Feldman, D. C. (2014). Subjective career success: A meta-analytic review. Journal of Vocational Behavior, 85(2), 169179. https://doi.org/10.1016/j.jvb.2014.06.001.

Ng, T. W. H., Eby, L. T., Sorensen, K. L., \& Feldman, D. C. (2005). Predictors of objective and subjective career success: A meta-analysis. Personnel Psychology, 58(2), 367-408. https://doi.org/10. 1111/j.1744-6570.2005.00515.x.

Nunnally, J. C. (1978). Psychometric theory (2nd ed.). New York: McGraw-Hill.

O'Boyle, E. H., Forsyth, D. R., Banks, G. C., \& McDaniel, M. A. (2012). A meta-analysis of the dark triad and work behavior: A social exchange perspective. The Journal of Applied Psychology, 97(3), 557579. https://doi.org/10.1037/a0025679.

O'Reilly, C. A., Chatman, J., \& Caldwell, D. F. (1991). People and organizational culture: A profile comparison approach to assessing person-organization fit. Academy of Management Journal, 34(3), 487-516. https://doi.org/10.2307/256404.

Paulhus, D. L. (1998). Interpersonal and intrapsychic adaptiveness of trait self-enhancement: A mixed blessing? Journal of Personality and Social Psychology, 74(5), 1197-1208. https://doi.org/10.1037/ 0022-3514.74.5.1197.

Paulhus, D. L., \& Williams, K. M. (2002). The dark triad of personality: Narcissism, Machiavellianism, and psychopathy. Journal of Research in Personality, 36(6), 556-563. https://doi.org/10.1016/ S0092-6566(02)00505-6.

Pincus, A. L., Ansell, E. B., Pimentel, C. A., Cain, N. M., Wright, A. G. C., \& Levy, K. N. (2009). Initial construction and validation of the pathological narcissism inventory. Psychological Assessment, 21(3), 365-379. https://doi.org/10.1037/a0016530.

Raskin, R., \& Terry, H. (1988). A principal-components analysis of the narcissistic personality inventory and further evidence of its construct validity. Journal of Personality and Social Psychology, 54(5), 890-902. https://doi.org/10.1037/0022-3514.54.5.890.

Schütz, A., Marcus, B., \& Sellin, I. (2004). Die Messung von Narzissmus als Persönlichkeitskonstrukt: Psychometrische Eigenschaften einer Lang- und einer Kurzform des Deutschen NPI (narcissistic personality inventory) [the measurement of narcissism as a personality construct: Psychometric features of a long and short version of the 
German narcissistic personality inventory]. Diagnostica, 50(4), 202-218. https://doi.org/10.1026/0012-1924.50.4.202.

Smith, M. B., Craig Wallace, J., \& Jordan, P. (2016). When the dark ones become darker: How promotion focus moderates the effects of the dark triad on supervisor performance ratings. Journal of Organizational Behavior, 37(2), 236-254. https://doi.org/10.1002/ job.2038.

Soyer, R. B., Rovenpor, J. L., Kopelman, R., Mullins, L., \& Watson, P. (2001). Further assessment of the construct validity of four measures of narcissism: Replication and extension. The Journal of Psychology, 135(3), 245-258. https://doi.org/10.1080/ 00223980109603695.

Spain, S. M., Harms, P., \& LeBreton, J. M. (2014). The dark side of personality at work. Journal of Organizational Behavior, 35(S1), S41-S60. https://doi.org/10.1002/job.1894.

Spurk, D., Keller, A. C., \& Hirschi, A. (2016). Do bad guys get ahead or fall behind? Relationships of the dark triad of personality with objective and subjective career success. Social Psychological and
Personality Science, 7(2), 113-121. https://doi.org/10.1177/ 1948550615609735.

Streiner, D. L. (2003). Starting at the beginning: An introduction to coefficient alpha and internal consistency. Journal of Personality Assessment, 80(1), 99-103. https://doi.org/10.1207/ S15327752JPA8001_18.

Thoresen, C. J., Kaplan, S. A., Barsky, A. P., Warren, C. R., \& de Chermont, K. (2003). The affective underpinnings of job perceptions and attitudes: A meta-analytic review and integration. Psychological Bulletin, 129(6), 914-945. https://doi.org/10.1037/ 0033-2909.129.6.914.

Wink, P. (1991). Two faces of narcissism. Journal of Personality and Social Psychology, 61(4), 590-597. https://doi.org/10.1037//00223514.61.4.590.

Publisher's Note Springer Nature remains neutral with regard to jurisdictional claims in published maps and institutional affiliations. 